\title{
Short Communication New record of Indian oil sardine Sardinella longiceps from the coastal region of Bangladesh
}

\author{
SHAMSUNNAHAR ${ }^{1}$, MOHAMMAD ABDUL BAKI ${ }^{1}$, ANIRBAN SARKER ${ }^{1}$, MOST. HASINA BEGUM, ${ }^{1}$ \\ A.B.M. ZAFARIA ${ }^{1}$, NAFISA NAWAL ISLAM ${ }^{2}$, MD. SAGIR AHMED ${ }^{3, \bullet}$ \\ ${ }^{1}$ Laboratory of Advanced Fisheries and DNA Barcoding, Department of Zoology, Jagannath University. Dhaka 1000, Bangladesh. Tel.:/fax.: +880-2- \\ 9667222, ”email: sagir@du.ac.bd \\ ${ }^{2}$ Department of Genetic Engineering and Biotechnology, Jahangirnagar University. Savar, Dhaka 1342, Bangladesh \\ ${ }^{3}$ Department of Zoology, University of Dhaka. Dhaka 1000, Bangladesh
}

Manuscript received: 10 May 2017. Revision accepted: 5 June 2017.

\begin{abstract}
Shamsunnahar, Baki MA, Sarker A, Hasina Begum M, Zafaria M, Islam NN, Ahmed MdS. 2017. New record of Indian oil sardine Sardinella longiceps from the coastal region of Bangladesh. Ocean Life 1: 11-13. We report the first record of Indian oil sardine Sardinella longiceps from the southern coast of the Bay of Bengal, Bangladesh. The sample specimens were collected from Pathorghata, Barguna, Bangladesh on 25th October, 2015. Morphometric and meristic studies were performed for taxonomic identification. Genomic DNA was extracted from tissue samples and mitochondrial Cytochrome Oxidase Subunit I (COI) gene was amplified for molecular characterization of this species. The morphometric and meristic data and DNA barcoding confirm the presence of $S$. longiceps in Bangladesh. This report updates the geographical distribution for this species confirming its presence in the coastal region of Bangladesh, and extends the number of marine fish known from the area.
\end{abstract}

Keywords: Sardinella longiceps Bangladesh, COI gene, DNA barcoding

Abbreviations: BLAST $=$ Basic Local Alignment Search Tool, COI $=$ Cytochrome $\mathrm{c}$ oxidase subunit I gene, DNA $=$ Deoxyribonucleic acid, FAO = Food and Agricultural Organization

\section{INTRODUCTION}

Indian oil sardine (S. longiceps) is a commercially important clupeid fish throughout the world. The species is a coastal pelagic and strongly migratory, with a geographical distribution limited to Arabia, Mombasa, Seychelles, Iran, Pakistan, India, Ceylon, Java, Bali straits, North Borneo and the Philippines (Nair 1972; Mohanty 2004). According to the FAO this species is confined to the Indian Ocean (Northern and Western parts only), the Gulf of Aden and Gulf of Oman, but not the Red Sea or the "Gulf" eastward to the southern or Eastern coasts of India.

This study was conducted to resolve some questionable identification of sardine species found in the southern coast of Bay of Bengal. After surveying different coastal areas of the country, the presence of Sardinella longiceps is was confirmed based on morphometric analysis and DNA barcoding of the sample collected from Pathorghata, Barguna.

\section{MATERIALS AND METHODS}

Samples were collected on 25 October, 2015 from Pathorghata, Barguna $\left(22^{\circ} 19^{\prime} 37.24^{\prime \prime} \mathrm{N}\right.$ 91 $\left.{ }^{\circ} 50^{\prime} 12.14^{\prime \prime} \mathrm{E}\right)$. They were preserved in ice soon after collection and then kept frozen in a laboratory at $-18{ }^{\circ} \mathrm{C}$ until further use.
Morphometric and meristic characteristics were recorded using an FAO species identification sheet. Length was measured in $\mathrm{cm}$ scale. A portion of tissue was taken from the sample fish for genomic DNA extraction. DNA was extracted using the standard method (Ward et. al. 2005) with a little modification (Chowdhury et al. 2016).Universal fish primer(FishF1 and FishR1) was used (Ward et. al. 2005) for amplification of the COI gene. Amplified DNA was sequenced and BLAST usedfor confirmation of the species.

The original voucher specimen DUZM 073 of $S$. longiceps is kept at the Museum of Department of Zoology, University of Dhaka and have public access. The DNA barcoding data can be retrieved from the NCBI GenBank; https://www.ncbi.nlm.nih.gov/nuccore/KX988263.

\section{RESULTS AND DISCUSSION}

\section{Description}

Morphometric analysis showed body depth of 4.0-4.4 $\mathrm{cm}$ and head length of $2.9-3.1 \mathrm{~cm}$ in standard lengths. Snouts were longer than the diameter of the eye, which was positioned 5.5-5.9 $\mathrm{cm}$ in length of head; maxillary extended to below anterior part or near to middle of eye. 188-214 gill rakers were positioned on the lower part of the anterior arch. Ventral scutes were sharply keeled, 26-29 in number. 
There were 16-18 dorsal fin rays, 14-16 anal fin rays, and 9 pelvic fin rays, below or behind the middle of the dorsal fin. A dark spot occurs at the edge of operculum (Figure 1).

Morphometric and meristic characteristics are given in table1 and compared with other published report (Raja 1968; Nair 1973).

\section{Remarks}

Morphomeristic characteristics of the specimens from the Bay of Bengal fall within the range limit of other specimens reported from the Indian Ocean (Nair 1970; Froese \& Pauly2016; Shah 2014). Meristic counts also fall within the range of previous work (Day 1865; Whitehead 1965; Nair 1972; Raja 1967; Froese \& Pauly 2016; Shah, 2014). The description of these specimens agrees with the work of Nair (1970) (Table 1).

The amplified COI gene was sequenced and BLAST (Basic Local Alignment Search Tool) with sequence deposited in the GenBank showed 99\% matching with sequence number JF4369381. The submitted sequence was assigned GenBank accession number KX988263 which confirms the molecular identification of Sardinella longiceps in this region.

Table. 1. Morphometric and meristic characteristicsof Sardinella longiceps

\begin{tabular}{llll}
\hline Characteristics & $\begin{array}{l}\text { Present study } \\
\text { (n=22) }\end{array}$ & Raja (1968) & Nair (1973) \\
\hline Total length (cm) & $17.67 \pm 0.65$ & - & - \\
Standard length (\% of TL) & $14.00 \pm 0.59(79.25)$ & - & - \\
Fork length (\% of TL) & $14.84 \pm 2.22(84)$ & - & - \\
Head length (\% of SL) & $4.75 \pm 0.33(33.93)$ & - & - \\
Eye diameter (\% of HL) & $0.83 \pm 0.08(17.41)$ & - & - \\
Body weight & $1.71 \pm 0.15$ & - & - \\
Body depth (\% of SL) & $3.4 \pm 0.25(24.29)$ & - & $16-18$ \\
Meristic characteristics & & & - \\
Dorsal fin ray & $16-18$ & $15-17$ & 9 \\
Pectoral fin ray & $15-17$ & $15-17$ & $14-16$ \\
Pelvic fin ray & 9 & 9 & $31-36$ \\
Anal fin ray & $14-18$ & $13-16$ & - \\
Scute & $26-29$ & - & \\
\end{tabular}

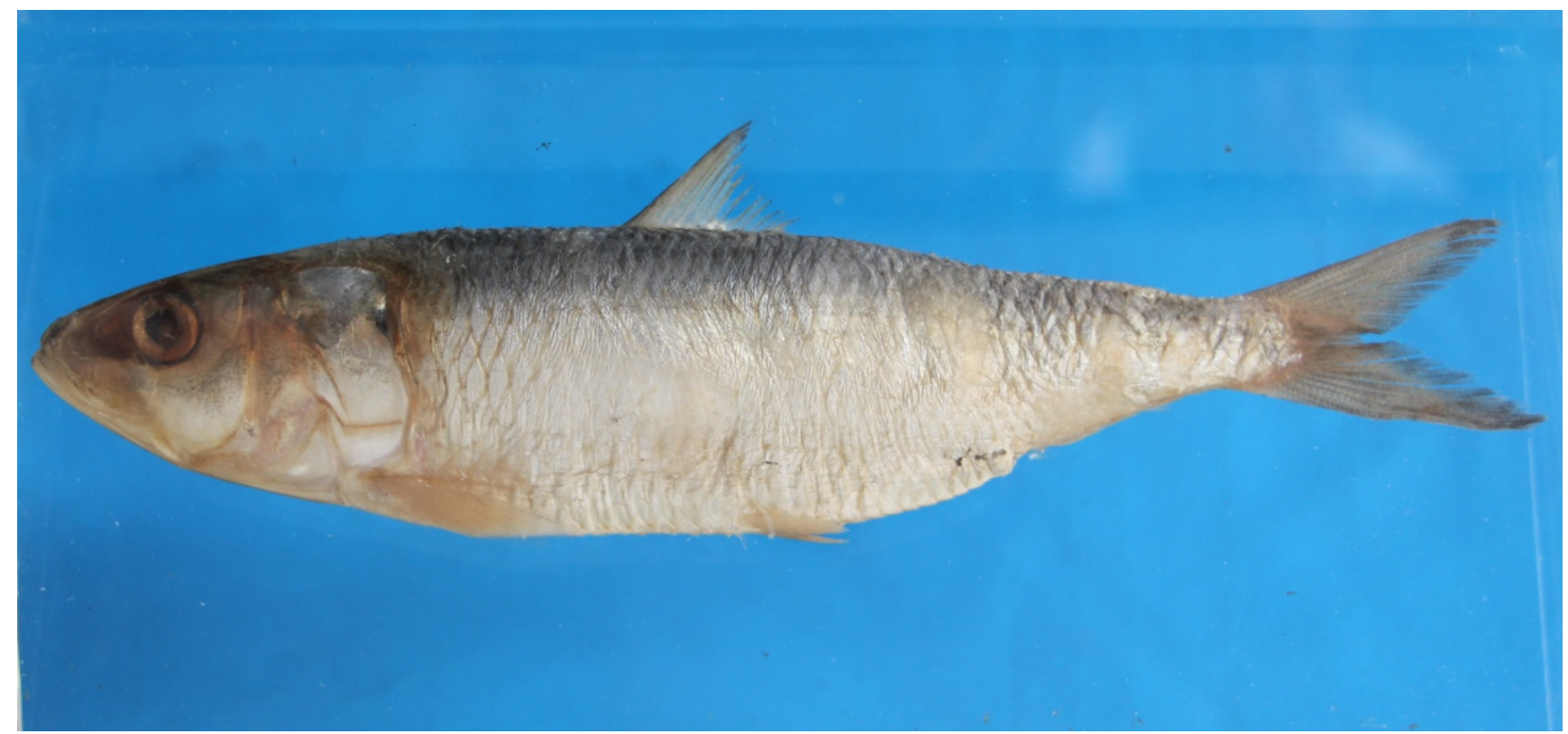

Figure 1. Sardinella longiceps (Lateral view) 
In conclusion, the nearest distribution of the species is reported from the Eastern coast of India (Froese \& Pauly, 2016). No previous occurrence is documented for this species from this area of the Bay of Bengal. The present study therefore extends the known geographical distribution of $S$. longiceps. In this area, the species will have been unknowingly commercially exploited along with other closely related species. This new taxonomic identification will be helpful for the proper management and conservation of this species in future.

\section{ACKNOWLEDGEMENTS}

We greatly acknowledge the partial financial support from the Ministry of Science and Technology, Government of Bangladesh as a form of NST Fellowship to the first author, Grants No. 39.00.0000.012.004.16-11(107). Authors' contributions: SN \& MSA: Molecular identification and write-up; MAB, AS \& AMBZ: Specimen collection and morphometric identification; NNI \& MHB: Experimental, Sequence editing and submission.

\section{REFERENCES}

Chan WL. 1965. Systematic revision of the Indo-Pacific clupeid fishes of the genus Sardinella (Family Clupeidae). Japanese Journal of Ichthyology 12:104-118 \& 13:1-39.

Chowdhury MM, Rahman ASMS, Nahar L, Rahman M, Reza HA, Ahmed MS. 2016. Efficiency of Different DNA Extraction Methods for Fish Tissues: A Comparative Analysis. IOSR Journal of Pharmacy and Biological Sciences 11(3) IV: 11-15.

Day F.1865.The Fishes of Malabar. Bernard Quaritch, 15 Picchadily, London. (Rep. by Bishen SinghMahendra Pal Singh, Dehradun).

Froese R, Pauly D. (Eds.). 2016. FishBase. World Wide Web electronic publication.

Mohanty PK, Khora SS, Panda US, Mohapatra GN, Mishra P. 2004. An Overview of Sardines and Anchovies Fishery along the Indian coasts. ICMAM Project.

Nair RV.1972. Indian Sardines: Their biology and fishery. CSIR Zoological Monograph no. 2, (Publication \& Information Directorate, CSIR, New Delhi.

Raja ABT. 1967. Length-weight relationship in the oil sardine, Sardinella longicepsVal. Indian Journal of Fisheries 14 (1\&2): 159-170.

Raja ABT. 1968. Studies on the systematic and biometrics of a few IndoPacific Sardines. [Dissertation]. University of Tokyo. [Japan]

Shah TH, Chakroborty SK, Jaiswar AK, Kumar T, Sandhya KM, Sadawarte RK. 2013. Biometric analysis of oil sardine Sardinellalongiceps, Valenceinnes, 1847 (Clupeiformes: Clupeidae) along Ratnagiri coast of Maharashtra. Indian journal of Geo marine science 43(5):805-814.

Ward RD, Zemlak TS, Innes BH, Last PR, Hebert PDN. 2005. DNA barcoding Australia's fish species. Phillosophical Transactions of The Royal Society B Biological Science: 1847-1857.

Whitehead PJ. 1965. A review of the elopoid and clupeid fishes of the Red Sea region. Bull. British Museum of Natural History (Zool) 12 (7): 227-281. 